\title{
Approaches to Teaching Rousseau: Confessions and Reveries of the Solitary Walker, edited by John C. o'Neal and Ourida Mostefai
}

\section{Paola Sosso}

\author{
(2) OpenEdition \\ Journals \\ Edizione digitale \\ URL: http://journals.openedition.org/studifrancesi/36202 \\ DOI: $10.4000 /$ studifrancesi.36202 \\ ISSN: 2421-5856

\section{Editore} \\ Rosenberg \& Sellier

\section{Edizione cartacea} \\ Data di pubblicazione: 1 juillet 2005 \\ Paginazione: 169 \\ ISSN: 0039-2944

\section{Notizia bibliografica digitale} \\ Paola Sosso, «Approaches to Teaching Rousseau: Confessions and Reveries of the Solitary Walker, \\ edited by John C. O'Neal and Ourida Mostefai», Studi Francesi [Online], 145 (XLIX | I) | 2005, online dal \\ 30 novembre 2015, consultato il 21 avril 2021. URL: http://journals.openedition.org/studifrancesi/ \\ 36202 ; DOI: https://doi.org/10.4000/studifrancesi.36202
}

Questo documento è stato generato automaticamente il 21 avril 2021.

\section{cc) (†)}

Studi Francesi è distribuita con Licenza Creative Commons Attribuzione - Non commerciale - Non opere derivate 4.0 Internazionale. 


\title{
Approaches to Teaching Rousseau: Confessions and Reveries of the Solitary Walker, edited by John C. o'Neal and Ourida Mostefai
}

\author{
Paola Sosso
}

\section{NOTIZIA}

Approaches to Teaching Rousseau: Confessions and Reveries of the Solitary Walker, edited by John C. o'NEAL and Ourida MOSTEFAI, New York, The Modern Language Association of America, 2003, pp. 157.

1 Il volumetto fa parte di una collana dal titolo "Approaches to Teaching World Literature" ed è rivolto agli insegnanti e agli studenti con l'intento di fare il punto su alcuni elementi essenziali del pensiero di Rousseau. La prima sezione, "Materials", illustra il ruolo e l'importanza delle Confessions e delle Rêveries all'interno delle opere del Ginevrino ed elenca le principali edizioni e traduzioni inglesi di riferimento per fornire poi brevi cenni bibliografici. La seconda sezione, "Approaches", include venti contributi raccolti in sei diversi capitoli. "Teaching Rousseau's Autobiographical writing" si apre con uno studio di Jean PERKINS che ripercorre alcune tappe della scrittura autobiografia mettendo in rapporto Rousseau, Sant'Agostino e Franklin (The Confessional Mode in Autobiogrphy: Saint Augustine, Rousseau and Banjamin Franklin, pp. 21-27); segue l'intervento di Mary Ellen BIRKETT che pone in relazione la scrittura di Rousseau con quella di Montaigne (Comparing Prefaces: Rosseau versus Montaigne, pp. 28-32). Guillemette JoHNSON si concentra in seguito su un approccio intertestuale (An Intertextual Aprroach to Teaching Rousseau's Confessions, pp. 33-38), mentre Christophe KELLY, esperto traduttore inglese delle opere del Ginevrino, riflette sulle difficoltà del rendere l'originale in un'altra lingua e conclude evidenziando l'utilità delle traduzioni 
per gli studenti universitari (Teaching Rousseau's Confessions in Translation, pp. 39-43). La seconda sezione, "From ths Confessions to the Rêveries", si apre con lo studio di Michael O'DEA dal titolo "Tout le Monde se Tut": Problems of Rhetoric in Rousseau's Autobiographical (pp. 44-49) nel quale l'autore offre un interessante approccio allo studio delle Confessions e delle Rêveries presentando affinità e differenze tra i due testi ed invitando ad approfondire questa direzione di analisi. Significativo e singolare anche il punto di vista adottato da Byron R. wELLS, che nella sua analisi inverte gli elementi in gioco, partendo dalla lettura delle Rêveries per concludere con le Confessions (From Reverie to Confession: Writing and reading a life Story, pp. 50-54). La terza sezione, dal titolo "Problems of reception", include uno studio di Patrick COLEMAN The Dangers of Telling It All, pp. 55-61), in cui lo studioso mostra come la scrittura del Ginevrino intenda creare una forte connivenza con il lettore parlando apertamente di vari aspetti della sua vita, mostrando la purezza dei suoi sentimenti e la sua totale sincerità. Affascinante l'intervento di Raymond TROUSSON (Public Prosecutor: Servan and the reception of the Confessions, pp. 62-67), che parte dal testo in cui Servan critica l'autobiografia di Rousseau (Eclaircissements sur la vie et les écrits de J.-J. Rousseau, 1783), considerandola pericolosa per la morale pubblica, per mostrare come gli scritti di Rousseau suscitarono opposte e vivaci reazioni tra i contemporanei. Chiude questa sezione l'articolo di Ourida mostefai dal titolo The Author as Celebrity and Outcast: Authorship and Autobiography in Rousseau (pp. 68-72). "Close Readings" è il titolo della quarta sezione che include saggi di Christie MCDONALD Truth and the other in Rousseau's Confessions, pp. 73-78), Thomas M. KAVANAGH, (Rousseau's Lottery, pp. 84-89), Sarah HERBOLD (Genre and Feminine Duplicity in the Confessions, pp. 84-89), Virginia E. SWAIN (The Mecanics of Language: Personification in the Rêveries, pp. 90-95), John O'NeAL (The Perceptual Metamorphosis of the Solitary Waker, pp. 96-103). Basata su un approccio comparativo è invece la quinta parte del volume: un primo articolo si concentra sul rapporto tra JeanJacques e il Romanticismo (Carl FICHER, The Public and the Self; Rousseau and Romanticism, pp. 104-109), mentre l'analisi successiva ad opera di Lorraine J. ClarK mette a fuoco Sympathy and Sensibility in Rousseau's Sixth Walk and Wordsworth's "The old Cumberland Beggar" (pp. 110-114). Di rilievo l'analisi di Jean STAROBINSKI, dal titolo From the Solitary Walker to the Flâneur: Baudelaire's Caricature of Rousseau (pp. 115-120), in cui l'eminente studioso misura la distanza che separa i due autori evidenziando come Baudelaire trasformi e inverta il modello rousseauiano in modo molto netto. L'ultima sezione, dal titolo "Contemporary Critical Approaches", presenta tre studi: Marie-Hélène HUET si occupa di Altered States (pp. 121-126), Pierre SAINT-AMAND di Rêveries of Idleness (pp. 127-131), Christine ROULSTON di Reading Rousseau's women: Autobiography and Femininity in the Confessions (pp. 132-136). Chiude il volumetto un Appendix che offre una rapida cronologia della vita di Rousseau, una lista delle opere, una breve presentazione degli studiosi che hanno contribuito alla redazione del testo e l'indice dei nomi citati. 